ISSN 0103-5150

Fisioter. Mov., Curitiba, v. 28, n. 1, p. 49-59, Jan./Mar. 2015

Licenciado sob uma Licença Creative Commons

DOI: http://dx.doi.org.10.1590/0103-5150.028.001.A005

\title{
Association among body composition, muscle performance and functional autonomy in older adults
}

\author{
Associação entre composição corporal, desempenho \\ muscular e autonomia funcional na terceira idade
}

\author{
Bruno Lucas Gonçalves ${ }^{[a]}$, Fernando Silva Guimarães ${ }^{[b, c]}$, Marcel Lima Lessa de Souza ${ }^{[b]}$, \\ Arthur de Sá Ferreira ${ }^{[b, d]}$, Míriam Raquel Meira Mainenti ${ }^{[b, e] *}$ \\ [a] Universidade Gama Filho (UGF), Rio de Janeiro, RJ, Brazil \\ [b] Centro Universitário Augusto Motta (Unisuam), Rio de Janeiro, RJ, Brazil \\ [c] Universidade Federal do Rio de Janeiro (UFRJ), Rio de Janeiro, RJ, Brazil \\ [d] Universidade Salgado Filho de Oliveira (Universo), Rio de Janeiro, RJ, Brazil \\ [e] Escola de Educação Física do Exército (EsEFEx), Rio de Janeiro, RJ, Brazil
}

\begin{abstract}
Introduction: Decrease in muscle mass and increase in body fat are important changes that occur with aging. Strength decline and worse resistance to fatigue can lead to a decreased functional autonomy of the elderly. Objective: The present study aimed to verify the existence of a relationship between body composition, muscle strength, lower limbs fatigue and functional autonomy in active elderly women. Materials and methods: The sample consisted of 29 elderly women with a mean age of $68.2( \pm 7.3)$ years. Body composition was analyzed by total and segmental bioelectrical impedance. Muscle fatigue was assessed using
\end{abstract}

\footnotetext{
* BLG: MSc, e-mail: blgfisio@gmail.com

FSG: PhD, e-mail: fguimaraes_pg@yahoo.com.br MLLS: MSc, e-mail: marcellimalessa@yahoo.com.br ASF: PhD, e-mail: arthur_sf@ig.com.br

MRMM: PhD, e-mail: miriam.mainenti@hotmail.com
} 
electromyography, through the analysis of median frequency and root mean square during a 60-second sustained isometric knee extension contraction, at $50 \%$ of the maximum voluntary isometric contraction. Functional autonomy was assessed by using the Latin American Development Group for Maturity (GDLAM) protocol. Results: There were significant correlations between height and strength $(r=0.49)$, age and lean body mass $(r=-0.42)$, body fat percentage (BF\%) and GDLAM tests $(r=0.39-0.41)$. The lean body mass was positively correlated with strength $(r=0.55)$, but not with resistance to fatigue. Conclusion: The lean body mass of the analyzed sample was found to be associated with the performance on the maximum strength test, but not with the performance on the resistance to fatigue test. This shows that these two parameters (strength and fatigue) are independent of one another. Elderly women with higher BF\% showed worse performance on the GDLAM tests. This evidences that individuals with high adiposity levels tend to have a more limited functional autonomy.

Keywords: Aging. Quadriceps muscle. Adiposity. Musculoskeletal system. Physical fitness.

\section{Resumo}

Introdução: A diminuição da massa muscular e o aumento da gordura corporal são alterações marcantes do envelhecimento. $O$ declínio de força e de resistência à fadiga pode levar o idoso à diminuição da autonomia funcional. Objetivo: O presente estudo teve como objetivo verificar a existência de relação entre composição corporal, força muscular, fadiga de membros inferiores e autonomia funcional em idosas ativas. Materiais e métodos: A amostra foi constituída de 29 idosas com idade média de 68,2 ( $\pm 7,3)$ anos. Foram analisadas a composição corporal pela bioimpedância total e segmentar e a fadiga muscular por meio da eletromiografia, pelos valores de frequência mediana e da raiz quadrática média, em um teste de um minuto a 50\% da contração voluntária máxima. A autonomia funcional foi avaliada pelo protocolo do Grupo de Desenvolvimento Latino-Americano para a Maturidade (GDLAM). Resultados: Foram observadas correlações significativas entre estatura e força $(r=0,49)$, idade e massa magra $(r=-0,42)$, percentual de gordura $(\% G)$ e testes do GDLAM ( $r$ de 0,39 a 0,41). A massa magra se correlacionou positivamente com a força $(r=0,55)$, mas não com o resultado do teste de resistência à fadiga. Conclusão: A massa magra das idosas avaliadas está associada ao desempenho no teste de força máxima, mas não no de resistência à fadiga, mostrando que esses dois parâmetros (força e fadiga) se comportam de maneira independente. As idosas com maior \% G tiveram um pior desempenho no GDLAM, mostrando que indivíduos idosos com maiores níveis de adiposidade corporal apresentam mais limitações relacionadas à autonomia funcional.

Palavras-chave: Envelhecimento. Músculo quadríceps. Adiposidade. Sistema musculoesquelético. Aptidão física.

\section{Introduction}

Population aging is a global reality. In Brazil, the gradual decline in infant mortality and fertility rates as well as the increase in life expectancy contributes to the population aging process (1). According to the IBGE (Brazilian Institute of Geography and Statistics), in 30 years from now, the elderly population in Brazil will exceed 30 million, accounting for nearly $13 \%$ of the population. The greater longevity of women compared to men (eight years, in average) leads to the feminization of the elderly population. Between 1991 and 2000 the proportion of elderly women increased from $54 \%$ to $55.1 \%$ of the population (2).

The increase in life expectancy causes great concern about the quality of life of the elderly in their last years of life, because significant changes in body composition are associated with aging, such as reduced muscle mass (sarcopenia) and increased body fat, leading to a high prevalence rate of chronic diseases and functional disabilities. These changes in body composition are more quickly observed in less physically active elders $(3,4)$. 
The use of bioimpedance to assess body composition has been gaining ground in recent decades. Because of its low cost and practicality, this instrument has been used in several scientific studies (5-7). It assesses body composition by applying a painless low-intensity electrical current to the body through electrodes attached to the skin. Impedance, calculated according to reactance $(\mathrm{Xc})$ and resistance $(\mathrm{R})$ values, is low in lean tissue, which contains large amounts of water and electrolytes, but relatively high in adipose tissue $(6,8,9)$.

During life, muscle size decreases on average about 30 to $40 \%$ and the lower limbs are more affected than the upper limbs (10). Gradual disuse and inactivity are some of the factors related to these changes which cause decline in muscle strength and fatigue resistance, affecting the physical performance of the elderly $(2,11)$. Although the term fatigue is well-known, it is not yet properly defined in the scientific realm. Classically, muscle fatigue is defined as the moment in which the muscle is unable to continue to develop or sustain a required force (12-15). Because there are many causes of fatigue and many places where it may occur, there is still no universally valid method to measure it (13). However, surface electromyography (EMG) is a noninvasive method that has been considered reliable to objectively and quantitatively determine the process of localized muscle fatigue through the analysis of median frequency (MF) and root mean square (RMS) of the electromyographic signal $(13,15-19)$.

Given the decreased functional autonomy of the elderly person and the associated changes in body composition experienced over time, as well as the scant attention received in the literature by localized muscle fatigue in the elderly, this study aimed to verify the existence of a relationship among body composition, muscle strength, fatigue of the lower limbs and functional autonomy in active elderly women, through the analysis of bioimpedance, surface electromyography and functional tests.

\section{Materials and methods}

This cross-sectional study was carried out in a single visit to the Human Movement Analysis Laboratory (LAMH) of the Augusto Motta University Center (Unisuam), where we assessed body composition by bioelectrical impedance, localized muscle fatigue in the vastus medialis muscle by surface electromyography (EMG) and functional autonomy through the Latin American Development Group for Maturity (GDLAM) protocol.

\section{Sample}

A convenience sample of 29 elderly women (aged $68.2 \pm 7.3$ years) living in the city of Rio de Janeiro and attending the 'University Open to the Third Age' (UNATI) of the institution where this study was conducted. The elderly were invited to participate in the study through a verbal announcement made during weekly activities. The inclusion criteria were: female individuals aged 60 years or older who exercised systematically at least twice a week, and voluntarily agreed to participate in the study. Exclusion criteria were: having musculoskeletal injuries that could impair performance on isometric tests, being on medication that could affect the water balance, using a pacemaker, having unstable heart failure, severe hypertension, edema or fluid retention. All participants signed an informed consent form. This study was approved by the institutional Ethics Committee (019/10, CAAE 0007.0.307.000-10), in accordance with Resolution 196/96 of the National Health Council.

\section{Experimental protocol}

The researcher and subjects first met for a prescheduled interview. During the interview the researcher asked the subjects questions about their personal characteristics and health condition, and also informed them about the research procedures. At the end of the interview, we measured the participants' body weight on an anthropometric mechanical scale accurate to $0.1 \mathrm{~kg}$ (R110, Welmy, Santa Barbara d'Oeste, São Paulo, Brazil), their height (measured while the subject held a deep breath and had her back turned to the anthropometric ruler of the scale), and the length of their lower limbs (distance from the anterior superior iliac spine ASIS - to the medial malleolus).

The bioimpedance was determined by bioelectrical impedance analysis (BIA) (310e Bioimpedance analyzer; Biodynamics; Seattle, WA, USA) in two ways, namely: $1^{\text {st }}-$ whole-body and $2^{\text {nd }}-$ segment. Both 
measurements were made on the dominant side of the body of all subjects. During the whole-body assessment, the subject was positioned supine (for five minutes) with their arms abducted $30^{\circ}$ from midline and their hips abducted $45^{\circ}$. Disposable $\mathrm{Ag} / \mathrm{AgCl}$ electrodes overlaminated with a siliconized polyester liner (3M, São Paulo, Brazil) were attached to the skin surface, which was cleaned with $92.8 \%$ hydrated ethanol. The electrodes were attached to the hand, wrist, ankle and foot of the dominant side of the body, with a 5 -cm distance between them. After the preparation of the subject and a 5-minute rest in this position, the electric current was applied, and the resistance and reactance values were recorded. Fat-free mass was calculated using an equation by Kyle et al. (20), because it has been validated for a wide age range (up to 94 years) (21).

Segmental bioimpedance was measured by the same device, with the skin cleaned as in the wholebody measurement and with the same distance between the electrodes, which were attached to the ASIS and medial malleolus of the dominant leg. To measure reactance and resistance, each subject was assessed at two times. The first time, the subject was positioned supine, in the same position described for the whole body measurement. To predict segmental lean mass, we calculated the ratio of the square of the length of the lower limb to the resistance (Length ${ }^{2}$ / Resistance), which has been shown by a previous study to correlate with the local lean mass (22).

The second time, the subject remained seated on the fitness station (Kenkorp 1500) with her knees flexed at $90^{\circ}$, the trunk touching the backrest, the arms crossed with both hands resting on the anterior region of the contralateral shoulders Reactance and resistance values were recorded before and during the isometric knee extension test (at 30 seconds and 60 seconds) at $50 \%$ of maximum voluntary isometric contraction, maintained for 60 seconds.

The subjects (in the sitting position) were also connected to surface electromyography (EMG-810 model; EMG system of Brazil LTDA). The electrodes were placed on the vastus medialis muscle of the dominant leg (laterality was assessed with one question: Which leg do you usually use to kick a ball?), with a 20-mm distance between them, in accordance with the recommendations of the SENIAM protocol (23). The reference electrode was attached to the contralateral medial malleolus. The maximal voluntary isometric knee extension contraction test was performed by instructing the subject to exert maximum force against the handle which was coupled to a load cell (DIN_TRO traction dynamometer) that was sensitive to tensile forces and had been previously attached to her ankle. Maximal voluntary isometric contraction was defined as the greatest force recorded during a total of three contractions maintained for five seconds with 30-second rest intervals between them.

The fatigue of the vastus medialis muscle was assessed through the analysis of MF and RMS during a 60-second sustained isometric knee extension contraction, at $50 \%$ of the maximum voluntary isometric contraction (MVIC) previously measured. In order to keep muscle contraction within $50 \%$ of the maximum, we used a visual feedback on the computer monitor, designed to facilitate the subject's performance. The quantification of fatigue was based on the verification of the slope of the linear regression line of the MF (MF Slope) and the RMS (RMS Slope). The software used for the acquisition and processing of electromyographic signals was the SuiteMYO $\left(\mathrm{PhD}^{2}\right.$ Consultoria e Sistemas Ltda., RJ, Brazil).

Functional autonomy was assessed through four tests which make up the Latin American Development Group for Maturity (GDLAM) protocol. They are, namely as follows: 1) 10-meter walk test (10MWT), which aims to assess the time a patient takes to walk 10 meters. 2) Rising from a sitting position (RSP), which aims to assess the functional capacity of the lower limbs. The test checks the time a patient takes to sit down and rise five times from a chair whose seat height is $50 \mathrm{~cm}$ (from the ground). 3) Rising from a ventral decubitus position (RVDP), which aims to evaluate the patient's ability to get up from the floor. The test starts with the patient in the ventral decubitus position, with his/her arms along the body. Its aim is to assess the time the patient takes to stand up after receiving a command from the examiner. 4) Rising from a chair and walking about the house (RCWH), which aims to assess the balance and agility of the elderly in daily life situations. A chair is fixed to the floor and two cones are placed diagonally to the chair, four meters from the back and three meters to each side of the chair. The test starts with the individual sitting on the chair. As soon as he/she hears the command "now", the subject should stand up and walk to the right, go round the cone and seat down on the chair again taking both feet off the ground. This procedure should be repeated, without hesitation, to the left. The whole procedure is repeated twice in a row without interruption, and the test is timed (24). 
The elderly women performed all GDLAM tests twice and were instructed to walk as fast as possible in all situations. The time was measured in seconds using a digital stopwatch (Oregon). The best time of the two runs was recorded. The collected data were analyzed separately and by using a general autonomy index (GDLAM index - GI), according to the times measured in the tests. The GI was calculated through the normalization of the data of the four autonomy tests in order to estimate a value in score units according to the equation [1] (24):

$$
\mathrm{Gl}=\frac{[(10 \mathrm{MWT}+\mathrm{RSP}+\mathrm{RVDP}) \times 2]+\mathrm{RCWH}}{3}
$$

where: $10 \mathrm{MWT}=$ time in seconds for the $10-\mathrm{m}$ walk test; RSP = time in seconds for the test of rising from a sitting position; RVDP = time in seconds for the test of rising from a ventral decubitus position; $\mathrm{RCWH}=$ time in seconds for the test of rising from a chair and walking about the house.

\section{Statistical analysis}

Considering as the main outcome the association between muscle function and GDLAM variables, we estimated a sample of 28 volunteers in order to obtain a minimum association of 0.41 with $\alpha=5 \%$ and $\beta=$ $70 \%$. Correlation analyzes were performed to verify the association between muscle fatigue and body composition (whole and segmental). In order to choose between Pearson's correlation analysis (for parametric data) and Spearman's correlation analysis (for nonparametric data), we first checked the normal distribution of the data by using the Kolmogorov-Smirnov test. To compare the resistance and reactance values during the fatigue test, we used an one-way analysis of variance (ANOVA). The statistical software SPSS 13.0 for Windows was used for all statistical analyses. Significance level was 5\% for all analyses.

\section{Results}

The Kolmogorov-Smirnov test showed that the analyzed variables had a normal distribution. Thus, we chose statistical tests and results presentation strategies (mean \pm standard deviation) for parametric data. Table 1 shows the characteristics of the sample and the results of the assessments of whole body composition, MVIC and localized muscle fatigue. All 29 participants were assessed for MF and RMS, but only 21 obtained values compatible with the characterization of fatigue (positive RMS Slope positive and negative MF Slope). Thus, only these data were analyzed in the associations involving Slope values.

The results obtained in the tests of the GDLAM protocol are shown (in seconds) in Table 2, as well as the General Index, which considers the performance on the four tests of the protocol in order to assess functional autonomy.

Table 3 shows Pearson's correlation coefficients and the significance of relationship ( $\mathrm{p}$-value) between variables. In this analysis, we found some negative associations: the higher the age, the lower the muscle mass; the higher the percentage of fat, the worse the performance on the RSP and RVDP tests, and on the GDLAM general index. We also identified positive associations: the greater the height, the greater the muscle strength in MVIC; the higher the lean body mass, the greater the strength. Despite the positive and significant association between muscle mass and MVIC, we found no similar correlation between muscle mass and resistance to fatigue. Similar results were observed for Length ${ }^{2} /$ Resistance, and strength and resistance to fatigue parameters (Figure 1).

The resistance and reactance values did not vary significantly during the fatigue test. The following resistance values were found in the pretest, and at 30 s and 60s: $262.54 \pm 37.17 ; 258.74 \pm 32.16$; and $259.38 \pm 30.87 \Omega$, respectively ( $p=0.99$ ). As for the reactance, the following values were found: $22.62 \pm$ $16.31 ; 26.96 \pm 18.56$; and $27.19 \pm 19.19 \Omega$, respectively $(\mathrm{p}=0.67)$.

\section{Discussion}

This study showed that lean mass influenced full strength, but not resistance to fatigue in the elderly women studied. Another interesting finding is the association between body fat percentage and performance on functional autonomy tests.

Individuals with higher lean mass produced greater muscle strength for knee extension in the MVIC test. These individuals probably have suffered 
lower deleterious effects on their muscular system, and therefore are able to produce higher levels of strength, when compared to individuals with higher fat mass. This relationship was expected, given that muscle strength is directly related to muscle size (10.24), which may also explain the positive relationship between height and MVIC found in the results.

The fact that muscle size decreases considerably with aging, causing decline in muscle strength and physical performance, is very well documented in the literature $(2,10,11)$. The results of this study support the positive relationship between advanced age and decreased lean body mass. Thus, age and lean body mass are factors that influence the maximum isometric strength of the elderly. Age shows an inverse relationship: the older the person, the lower the strength achieved. Lean body mass show a direct relationship: the higher the lean body mass, the greater the maximum strength achieved.

Table 1 - Sample characteristics and results of the tests of BIA, Maximum Strength and Resistance to Fatigue

\begin{tabular}{lccc}
\hline & Minimum & Maximum & Mean \pm SD \\
\hline Age (years) & 60 & 85 & $67.8 \pm 7.6$ \\
Weight $(\mathrm{kg})$ & 55.1 & 96.6 & $68.5 \pm 10.2$ \\
Height $(\mathrm{m})$ & 143 & 164 & $153.8 \pm 5.5$ \\
BMI $\left(\mathrm{kg} / \mathrm{m}^{2}\right)$ & 23.9 & 37.3 & $28.9 \pm 3.5$ \\
BIA Body fat \% & 31.8 & 51.9 & $40.7 \pm 4.9$ \\
BIA Lean Body Mass (kg) & 34.4 & 51.5 & $40.3 \pm 4.5$ \\
BIA Fat Body Mass $(\mathrm{kg})$ & 19.0 & 50.1 & $28.1 \pm 7.2$ \\
Length2/Resistance & 18.6 & 26.9 & $22.5 \pm 2.4$ \\
MVIC (kg.f) & 7.9 & 47.6 & $29.0 \pm 10.1$ \\
RMS Slope & 0.137 & 1.118 & $0.552 \pm 0.304$ \\
MF Slope & -1.724 & -0.151 & $-0.505 \pm 0.340$ \\
\hline
\end{tabular}

Note: $\mathrm{BIA}=$ body bioimpedance; $\mathrm{BMI}=$ body mass index; MVIC = maximal voluntary isometric contraction of the quadriceps; RMS Slope = angle of the linear regression line obtained from the root mean square values of the electromyographic signal during the resistance to fatigue test; MF Slope = angle of the linear regression line obtained from the median frequency values of the electromyographic signal during the resistance to fatigue test; Length²/Resistance = ratio of the square of the length of the lower limb to the segmental bioimpedance resistance.

Table 2 - GDLAM protocol results

\begin{tabular}{|c|c|c|c|}
\hline GDLAM & Minimum & Maximum & Mean \pm SD \\
\hline 10MWT & 4.6 & 7.8 & $6.0 \pm 0.8$ \\
\hline $\mathrm{RSP}(\mathrm{s})$ & 6.1 & 10.5 & $8.3 \pm 1.3$ \\
\hline RVDP (s) & 2.1 & 12.5 & $4.4 \pm 2.7$ \\
\hline RCWH (s) & 32.2 & 53.9 & $40.0 \pm 5.9$ \\
\hline Gl & 19.5 & 38.4 & $25.8 \pm 4.6$ \\
\hline
\end{tabular}

Note: $10 M W T=10-\mathrm{m}$ walk test; RSP = rising from a sitting position; RCWH = rising from a chair and walking about the house; RVDP = rising from a ventral decubitus position; $\mathrm{Gl}=$ general autonomy index. 
Table 3 - Significant associations found in the study

\begin{tabular}{lcc}
\hline Variables & Pearson & p-value \\
\hline Age and Lean Body Mass & -0.42 & 0.027 \\
Height and MVIC & 0.49 & 0.007 \\
Lean Body Mass and MVIC & 0.55 & 0.003 \\
Length2/Resistance and MVIC & 0.40 & 0.050 \\
Body fat \% and RSP & 0.41 & 0.035 \\
Body fat \% and RVDP & 0.45 & 0.020 \\
Body fat \% and OI & 0.39 & 0.049 \\
\hline
\end{tabular}

Note: MVIC = maximal voluntary isometric contraction of the quadriceps; RVDP = rising from a ventral decubitus position; RSP = rising from a sitting position; $0 \mathrm{l}=$ overall autonomy index.
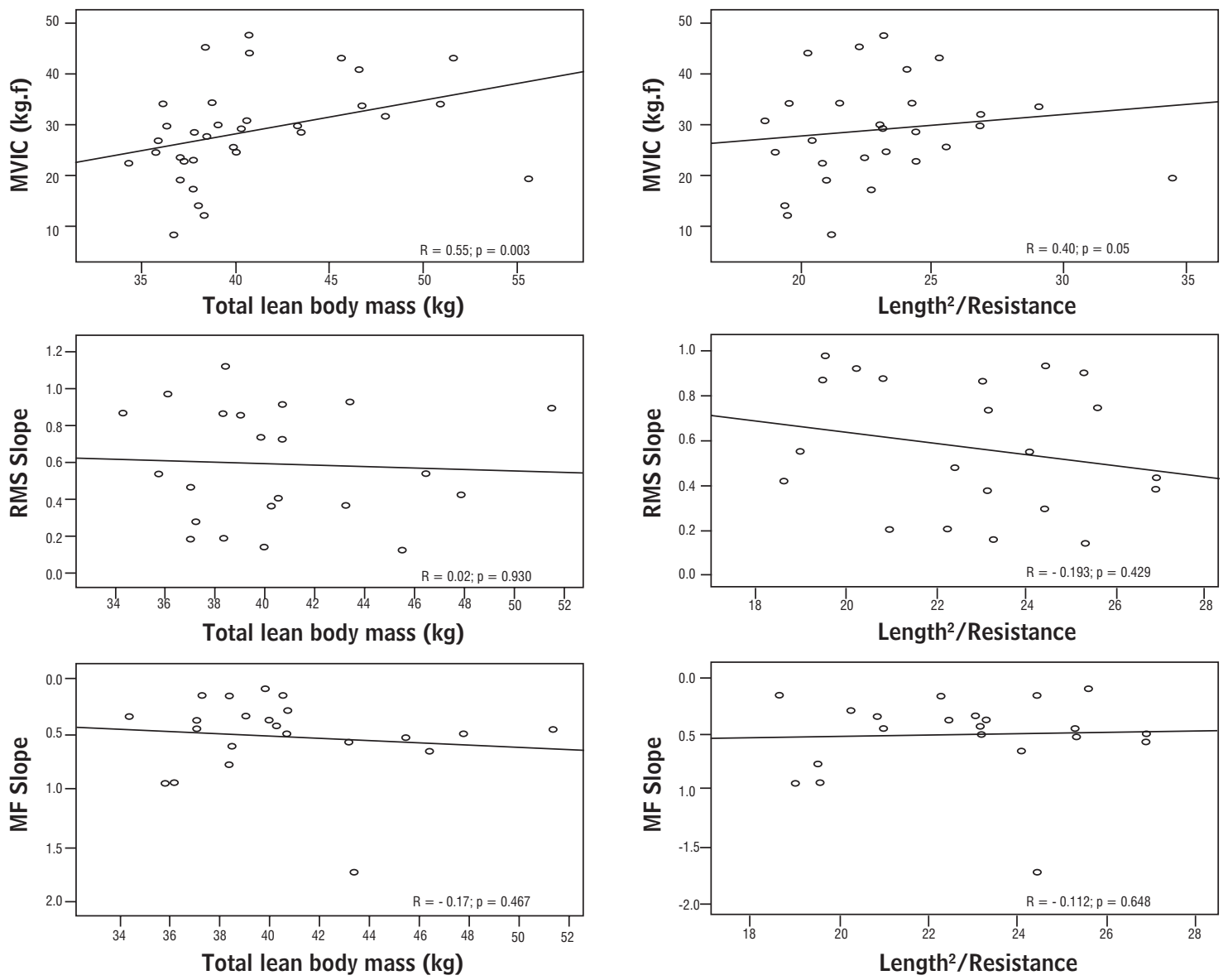

Figure 1 - Scatter point graphs showing the relationships between the values of strength and resistance to fatigue (MVIC $-1^{\text {st }}$ line, RMS Slope $-2^{\text {nd }}$ line, and FM Slope $-3^{\text {rd }}$ line) and the values of total lean body mass and Length ${ }^{2} /$ Resistance

Note: MVIC = maximal voluntary isometric contraction of the quadriceps; RMS Slope $=$ angle of the linear regression line obtained from the root mean square values of the electromyographic signal during the resistance to fatigue test; MF Slope = angle of the linear regression line obtained from the median frequency values of the electromyographic signal during the resistance to fatigue test; Length ${ }^{2}$ Resistance $=$ ratio of the square of the length of the lower limb to the segmental bioimpedance resistance. 
Although there are several causes of fatigue and different sites where it may occur (13), EMG has been frequently used in scientific studies to determine localized muscular fatigue in a quantitative manner. An increase in RMS values and/or decrease in the MF values characterize muscle fatigue $(13,15-18)$. Silva and Gonçalves (12) have analyzed localized muscle fatigue in the vastus medialis and vastus lateralis muscles of nine female volunteers aged between 18 and 22 years by using RMS values. They performed the 60 -second sustained isometric knee extension protocol $\left(90^{\circ}\right)$ at $20 \%, 30 \%, 40 \%$ and $50 \%$ of MVIC. They found that the values obtained at $20 \%$ and $30 \%$ were insufficient to be characterized as muscular fatigue. For this purpose, loads heavier than $30 \%$ of the MVIC were necessary. They have also reported the importance of using 60-second protocols in order to minimize the influence of psychological factors, which may occur when the subject is required to perform a test until exhaustion (12). Due to the findings aforementioned, a load of 50\% of MVIC was chosen to ensure the occurrence of fatigue in the sample of this study. Changes related to aging such as sarcopenia, reduced creatine phosphate levels, mitochondrial density, capillary density and blood supply (25-27) influence the resistance to fatigue. The reviewed literature is unanimous in stating that physical inactivity in the elderly is a major factor responsible for the deleterious effects of aging and that regular physical activity can significantly slow down this process $(10,11,14,27-29)$.

Interestingly, although the elders with higher lean body mass showed higher muscle strength, they did not show lower localized muscle fatigue in the RMS and MF analyses. This demonstrates that muscle strength and resistance to fatigue are independent of one another. These results are in agreement with those found by Lacourt and Marini, who have reported that the decrease in the cross-sectional area of the muscle is mainly due to the reduction in the fast contraction fibers (type II) (25). Localized muscular fatigue in the elderly is an important neuromuscular function parameter, but it is still rarely reported in the literature (12). It was expected that individuals with higher lean body mass would show higher resistance to fatigue (12). Individuals with higher fat body mass, due to their higher body weight and as observed in the studied sample, provide a constant resistance to the muscular system. This fact added to the trends of deleterious effects occurring to a greater extent in type II fibers (power) than in type I fibers (resistance) could explain this behavior in the resistance to fatigue and lean body mass parameters.

Increased body fat is an important factor associated with the aging process and may be harmful to health (1). The body composition can be measured by various methods, which are based on different principles and physical models and offer overall results or results for specific body regions. Body composition can be analyzed by simple methods, such as skinfold measurements and bioelectrical impedance analysis, or by more sophisticated methods such as hydrostatic weighing or DEXA (Dual-energy X-ray absorptiometry) $(6,30)$. Because it is low-cost and easy-to-use method, BIA has been frequently used in scientific studies $(3,31)$. Resistance and reactance values alone do not allow the direct assessment of total body fluid, body fat and fat-free body mass. Generally, predictive regression equations are used in order to make this assessment. These equations are validated from studies comparing bioimpedance and body composition assessment techniques considered "gold standard", such as hydrostatic weighing and DEXA (3).

The variability of the results described in the literature is related to the different equations and equipments used, to methodological differences in the populations studied, different data collection methods and influence on the hydration status (5, 6). Dey and colleagues have stated that BIA is only appropriate to assess body composition in epidemiological studies, in specific populations for which the predictive equations were tested. There are several predictive equations in the literature, and they are usually developed based on younger populations. Usually, they do not offer good accuracy when used for elderly populations (31). There are very few predictive equations developed for the elderly population. The main studies with this goal were conducted by Deurenberg et al. (3), Kyle et al. (20), Rech et al. (21), Baumgartner et al. (32), Svendsen et al. (33) and Roubenoff et al. (34).

Britto and Mesquita (9) have reported that the main source of error in measurements is related to factors that may alter the hydration status of the patient. Therefore the recommendations of the European Society of Enteral and Parenteral Nutrition (ESPEN), which were cited in the section "Methods" of this study, should be followed.

Another significant result was the correlation between the body fat percentage and the RSP and 
RVDP tests, and the GDLAM GI. The elderly women who had higher body fat percentage showed poorer performance on the tests and, consequently, worse GI. Thus, this study evidenced the importance of lean body mass and muscle strength for the improvement of functional capacity during aging. These results are supported by several authors $(35,36)$.

\section{Conclusion}

This study showed that physically active elderly with higher lean body mass had greater muscle strength. However, we found no correlation between lean body mass and resistance to fatigue. It also evidenced that older elders had lower body lean mass. With regard to the worse performance of elders with a higher percentage of body fat on the RSP and RVDP tests, and on the GDLAM GI, it can be said that older adults with higher levels of body fat have a more limited functional autonomy.

We suggest that future studies perform a comparative analysis of localized muscular fatigue between physically active and inactive elderly subjects, with loads equal to or greater than $50 \%$ of the MVIC, in order to clarify whether our findings related to resistance to fatigue were influenced by the characteristics of the sample, composed of active elderly women. In addition, protocols comparing the behavior of elderly subjects of both sexes would also add important knowledge to this area of study.

\section{References}

1. Aguiar CF, Assis M. Perfil das mulheres idosas segundo a ocorrência de quedas: estudo de demanda no Núcleo de Atenção ao Idoso da UnATI/UERJ. Rev Bras Geriatr Gerontol. 2009;12(3):391-404.

2. Instituto Brasileiro de Geografia e Estatística - IBGE. Perfil dos idosos responsáveis pelos domicílios no Brasil: 2000. Rio de Janeiro: IBGE; 2002.

3. Deurenberg P, van der Kooij K, Evers P, Hulshof T. Assessment of body composition by bioelectrical impedance in a population aged greater than $60 \mathrm{y}$. Am Soc Clin Nutri. 1990;5(1):3-6.
4. Pereira RJ, Cotta RMM, Franceschini SCC, Priore SE. Característica da saúde do idoso brasileiro. Rev Med Minas Gerais. 2009;19(1):44-50.

5. Rodrigues MN, Silva SC, Monteiro WD, Farinatti PTV. Estimativa da gordura corporal através de equipamentos de bioimpedância, dobras cutâneas e pesagem hidrostática. Rev Bras Med Esporte. 2001;7(4):125-31.

6. Rezende F, Rosado L, Franceschinni S, Rosado G, Ribeiro R, Marins JCB. Revisão crítica dos métodos disponíveis para avaliar a composição corporal em grandes estudos populacionais e clínicos. Arch Latinoamer Nut. 2007;57(4):327-34.

7. Mainenti MRM, Rodrigues EC, Oliveira JF, Ferreira AS, Dias CM, Silva ALS. Adiposity and postural balance control: correlations between bioelectrical impedance and stabilometric signals in elderly Brazilian women. Clinics. 2011;66(9):1513-8.

8. Kyle UG, Bosaeus I, De Lorenzo AD, Deurenberg P, Elia M, Gómes JM, et al. Bioelectrical impedance analysis part I: review of principles and methods. Clin Nutr. 2004;23(5):1226-43.

9. Britto EP, Mesquita ET. Bioimpedância elétrica aplicada à insuficiência cardíaca. Rev. SOCERJ. 2008; 21(3):178-83.

10. Prentice WE, Voight ML. Técnicas em reabilitação musculoesquelética. Porto Alegre: Artmed; 2003.

11. Kisner C, Colby LA. Exercícios terapêuticos: fundamentos e técnicas. São Paulo: Manole; 2009.

12. Silva SRD, Gonçalves M. Análise da fadiga muscular pela amplitude do sinal eletromiográfico. R Bras Ci e Mov. 2003;11(3):15-20.

13. Kumar S. Localized muscle fatigue: review of three experiment. Rev Bras Fisioter. 2006;10(1):9-28.

14. Paula RH, Vale RGS, Dantas EHM. Relação entre o nível de autonomia funcional de adultos idosos com o grau de fadiga muscular aguda periférica verificado pela eletromiografia. Fit Perform J. 2006;5(2):95-100.

15. Rondelli RR, Dal Corso S, Simões A, Malaguti C. Métodos de avaliação da fadigabilidade muscular periférica e seus determinantes energéticos-metabólicos na DPOC. J Bras Pneumol. 2009;35(11):1125-35. 
16. Merletti R, Lo Conte LR, Orizio C. Indices of muscle fatigue. J Electromyography Kinesiol. 1991;1(1):20-33.

17. Santos MCA, Semeghuini TA, Azevedo FM, Colugnati DB, Negão Filho RF, Alves N, et al. Análise da fadiga muscular localizada em atletas e sedentários através de parâmetros de frequência do sinal eletromiográfico. Rev Bras Med Esporte. 2008;14(6):509-12. doi: 10.1590/S1517-86922008000600007.

18. Fukuda TY, Echeimberg JO, Pompeu JE, Lucareli PRG, Garbelotti S, Gimenes RO, et al. Root mean square value of the electromyographic signal in the isometric torque of the quadriceps, hamstrings and brachial biceps muscle in female subjects. The J Appl Res. 2010; $10(1): 32-9$.

19. Ferreira AS, Guimarães FS, Silva JG. Aspectos metodológicos da eletromiografia de superfície: considerações sobre os sinais e processamentos para estudo da função neuromuscular. Rev Bras Cienc Esporte. 2010;31(2):11-30.

20. Kyle UG, Genton L, Karsegard L, Slosman DO, Pichard C. Single prediction equation for bioelectrical impedance analysis in adults aged 20-94 years. Nutrition. 2001;17(3):248-53.

21. Rech CR, Cordeiro BA, Petroski EL, Vasconcelos FAG. Validation of bioelectrical impedance for the prediction of fat-free mass in Brazilian elderly subjects. Arq Bras Endocrinol Metab. 2008;52(7):1163-71.

22. Bracco D, Thiébaud D, Chioléro RL, Landry M, Burckhardt P, Schutz AY. Segmental body composition assessed by bioelectrical impedance analysis and DEXA in humans. J Appl Physiol. 1996;81(6):2580-7.

23. Hermens HJ, Freriks B, Merletti R, Stegeman D, Blok J, Rau G, et al. European Recommendations for Surface ElectromyoGraphy: results of the SENIAM project. 2nd ed. Enschede, 1999.

24. Dantas EHM, Vale RGS. Protocolo GDLAM de avaliação da autonomia funcional. Fit Perform J. 2004; 3(3):175-82.

25. Lacourt MX, Marini LL. Decréscimo da função muscular decorrente do envelhecimento e a influência na qualidade de vida do idoso: uma revisão de literatura. Rev Bras de Ciên do Envelh Hum. 2006;3(1):114-21.
26. Mazini Filho ML, Zanella AL, Aidar FJ, Silva AMS, Salgueiro RS, Matos DG. Atividade física e envelhecimento humano: a busca pelo envelhecimento saudável. Rev Bras de Ciên do Envelh Hum. 2010;7(1):97-106.

27. Pícoli TS, Figueiredo LL, Patrizzi LJ. Sarcopenia e envelhecimento. Fisioter Mov. 2011;24(3):455-62.

28. Alencar NA, Souza Júnior JV, Aragão JCB, Ferreira MA, Dantas E. Nível de atividade física, autonomia funcional e qualidade de vida em idosas ativas e sedentárias. Fisioter Mov. 2010;23(3):473-81.

29. Bonganha V, Santos CF, Rocha J, Chacon-Mikahil MPT, Madruga VA. Força muscular e composição corporal de mulheres na pós-menopausa: efeitos do treinamento concorrente. Rev Bras Ativ Fis Saude. 2008; 13(2):102-9.

30. Barufaldi LA. Índice de massa corporal e valores de impedância bioelétrica de crianças e adolescentes indígenas Kaingang, Rio Grande do Sul Brasil [dissertação]. Porto Alegre: Universidade Federal do Rio Grande do Sul; 2009.

31. Dey DK, Bosaeus I, Lissner L, Steen B. Body composition estimated by bioelectrical impedance in the Swedish elderly. Development of population-based prediction equation and reference values of fat-free mass and body fat for 70- and 75-y olds. Eur J Clin Nutr. 2003;57(8):909-16.

32. Baumgartner RN, Heymsfield SB, Lichtman S, Wang J, Pierson Jr RN. Body composition in elderly people: effect of criterion estimates on predictive equations. Am J Clin Nutr. 1991;53(6)1345-53.

33. Svendsen OL, Haarbo J, Heitmann BL, Gotfredsen A, Christiansen C. Measurement of body fat in elderly subjects by dual-energy x-ray absorptiometry, bioelectrical impedance, and anthropometry. Am J Clin Nutr. 1991;53(5):1117-23.

34. Roubenoff R, Baumgartner RN, Harris TB, Dallal GE, Hannan MT, Economos CD, et al. Application of biolectrical impedance analysis to elderly populations. J Gerontol A Biol Sci Med Sci. 1997; 52(3): M129-36. 
35. Matsudo SM, Matsudo VKR, Barros Neto TL. Atividade física e envelhecimento: aspectos epidemiológicos. Rev Bras Med Esporte. 2001;7(1):2-13.

36. Matsudo SM, Matsudo VKR, Barros Neto TL. Impacto do envelhecimento nas variáveis antropométricas, neuromotoras e metabólicas da aptidão física. Rev Bras Ciên e Mov. 2000;8(4):21-32.

Received: 01/27/2014

Recebido: 27/01/2014

Approved: 09/12/2014

Aprovado: 12/09/2014 